\title{
Pelatihan Penyusunan Proposal PTK Kepada Para Guru Sekolah Dasar Di Gugus 3 Kabupaten Ende
}

\author{
Siprianus See ${ }^{*}$, Berty Sadipun 2, Marselina Wali 3, Gregorius We'u 4, Adi \\ Neneng Abdullah 5, Agustina Pali 6, Siti Arafat 7 \\ 1,2,3,4,5,6,7 Universitas Flores, Ende, Indonesia \\ *Corresponding Author: siprianussee@gmail.com
}

\begin{abstract}
Info Artike1 Diterima : 03/01/2021 Direvisi: 29/01/2021 Disetujui: 21/02/2021
Abstract. The responsibility of teachers as professional educators is imperative in carrying out their duties. To become professional teachers, elementary school teachers in cluster 3 of Ende sub-district feel the need to get enlightenment and scientific practice through training in the preparation of Classroom Action Research proposals, so that these teachers can create quality learning in the classroom. The method of this activity is in the form of training with stages starting from the presentation of the material by the resource team to the preparation of a Classroom Action Research proposal by the teachers. The results of this training show that on average the teachers are able to understand the concept of Classroom Action Research well with indicators that teachers can identify and determine the focus of research, determine learning strategies that are considered appropriate from relevant scientific literature, and can draft Classroom Action Research proposals. Thus this training activity has a positive impact on teacher professionalism in an effort to improve the competence of students in the classroom. For this reason, teachers are expected to continue to strive to carry out scientific activities, one of which is in the form of Classroom Action Research, so that teachers can morally continue to contribute to human resource development through the education sector.
\end{abstract}

Keywords: Teacher training, classroom action research, elementary school teachers

\begin{abstract}
Abstrak. Tanggung jawab guru sebagai pendidik yang profesional merupakan suatu keharusan dalam menjalankan tugasnya. Untuk menjadi guru yang profesional para guru SD di gugus 3 kecamatan Ende merasa perlu mendapat pencerahan dan praktik ilmiah melalui pelatihan penyusunan proposal PTK, agar para guru tersebut dapat menciptakan pembelajaran yang berkualitas di kelas. Metode kegiatan ini adalah berupa pelatihan dengan memiliki tahap-tahap yang dimulai dari persentasi materi oleh tim narasumber sampai pada penyusunan proposal PTK oleh para guru. Hasil kegiatan pelatihan ini menunjukan bahwa secara rata-rata para guru sudah mampu memahami konsep PTK secara baik dengan indikator para guru dapat mengidentifikasi dan menentukan fokus penelitian, menentukan strategi pembelajaran yang dianggap tepat yang bersumber dari literatur ilmiah yang relevan, dan dapat menyusun draft proposal PTK. Dengan demikian kegiatan pelatihan ini berdampak positif terhadap profesionalitas guru dalam upaya meningkatkan kompetensi peserta didik di kelas. Untuk itu para guru diharapkan untuk terus berupaya melaksankan aktivitas-aktivitas ilmiah salah satunya berupa PTK, sehingga guru secara moril dapat terus berkontribusi terhadap pembangunan SDM melalui bidang pendidikan.
\end{abstract}

Kata Kunci: Pelatihan guru, Penelitian Tindakan Kelas, Guru Sekolah Dasar

How to Cite: See, S., Sadipun, B., Wali, M., We'u, G., Abdullah, A. N., Pali, A., \& Arafat, S. (2021). Pelatihan Penyusunan Proposal PTK Kepada Para Guru Sekolah Dasar Di Gugus 3 Kabupaten Ende. Prima Abdika : Jurnal Pengabdian Masyarakat, 1(1), 7-13. https://doi.org/10.37478/abdika.v1i1.941

\section{Pendahuluan}

Kegiatan ini dilatarbelakangi atas dasar kebutuhan para guru mengenai PTK yang belum dilaksanakan secara ilmiah dan maksimal oleh para guru SD gugus 3 kecamatan Ende, dan juga atas tuntutan Tridharma perguruan tinggi bagi para dosen, dalam hal ini adalah tim dosen PGSD Uniflor. Selain itu kegitan ini juga sebagai bentuk tanggungjawab para guru SD dalam meningkatkan profesionalitasnya untuk dapat menciptakan kualitas pembelajaran yang lebih baik melalui kegiatan PTK. Sedangkan sebagai dosen di perguruan tinggi, kegiatan ini adalah sebagai 
bentuk pengabdian kepada masyarakat.

Kegiatan Pelatihan PTK Kepada Para guru di SD gugus 3 kecamatan Ende, sesungguhnya memiliki tujuan sebagai berikut; 1) memberikan bekal pengetahuan secara Ilmiah yang kemudian dihubungkan dengan fakta di lapangan mengenai PTK kepada para guru, 2) meningkatkan kualitas kompetensi profesionalitas guru dalam merencanakan, melaksnanakan, mengevaluasi, dan menyusun tindak lanjut pembelajaran di kelas, 3) membiasakan para guru untuk melaksanakan PTK sebagai solusi dalam menyelesaikan persoalan pembelajaran yang dihadapinya, 4) sebagai salah satu laporan atau bukti kinerja guru dalam mengusul kenaikan golongan.

Dalam proses belajar mengajar, guru mempunyai tugas dan tanggung jawab sebagai pendidik adalah membantu dan membimbing siswa untuk mencapai kedewasaan seluruh ranah kejiwaan sesuai dengan kriteria yang telah ditetapkan, baik kriteria institusioanal maupun kontitusioanal. Untuk dapat menjalankan tugas dan tanggung jawabnya itu, guru berkewajiban merealisasikan segenap upaya yang mengarah pada pengertian membantu dan membimbing siswa dalam melapangkan jalan menuju perubahan seluruh ranah kejiwaannya. Dalam hal ini, kegiatan nyata yang utama dalam memberi bantuan dan bimbingan itu adalah mengajar (Trianto, 2010). Tugas mengajar guru terlaksana pada pembelajaran yang berlangsung di kelas. Untuk mewujudkan pembelajaran yang berkualitas secara kontinu, maka guru perlu melakukan suatu tindakan ilmiah yang dapat membantu guru dalam mengatasi persoalan yang dihadapinya di kelas melalui penelitian tindakan kelas.

Penelitian Tindakan Kelas berfokus pada proses pembelajaran yang terjadi di kelas, bukan pada instrumen input kelas, seperti Silabus, Rencana Pelaksanaan Pembelajaran, materi dan lain-lainnya atau output (hasil belajar). Penelitian Tindakan Kelas mengkaji tentang hal-hal yang terjadi dalam proses pembelajaran di kelas. Makna kelas dalam Penelitian Tindakan Kelas adalah sekelompok peserta didik yang sedang belajar entah dalam kelas maupun di luar kelas berupa kegiatan karyawisata yang dilakukan oleh peserta didik, praktik di laboratorium, di bengkel, di rumah, atau di tempat lain atau ketika peserta didik sedang mengerjakan tugas yang diberikan oleh guru (Ekawarna, 2013). Penelitian tindakan (action research) dipandang sebagai kelanjutan penelitian eksperimen karena bukan untuk mengetes suatu perlakuan atau tindakan tetapi sudah mempunyai keyakinan akan ampuhnya suatu perlakuan atau tindakan atau juga disebut sebagai penelitian eksperimen dengan ciri khusus yakni memiliki bentuk strategis penelitian kualitatif yang berparadigma konstruktivis dan analisis siklus (Arifin 2010). Sementara Kemmis (1991) (dalam Taniredja, 2012) mengemukakan bahwa Penelitian Tindakan Kelas adalah sebuah bentuk inquiri reflektif yang dilakukan secara kemitraan mengenai situasi sosial tertentu termasuk di dalamnya pendidikan. Taniredja (2012) secara spesifik juga menjelaskan bahwa Penelitian Tindakan Kelas adalah sebuah kajian sistematik dari upaya perbaikan pelaksanaan praktek pendidikan oleh sekelompok guru dengan melakukan tindakan-tindakan dalam pembelajaran berdasarkan refleksi mereka mengenai hasil dari tindakan-tindakan tersebut. PTK adalah penelitian tindakan (action research) yang dilakukan dengan tujuan memperbaiki mutu praktik 
pembelajaran di kelasnya. PTK berfokus pada kelas atau pada proses belajar mengajar yang terjadi dikelas.Tujuan penelitian ini untuk meningkatkan mutu pembelajaran di kelas yang dialami langsung oleh guru dan peserta didik yang sedang belajar, memperbaiki kinerja peserta didik di sekolah dan memperbaiki penggunaan media pembelajaran, alat bantu belajar peserta didik, serta sumber belajar yang berkualitas (Arikunto, 2010). Dengan demikian kegiatan pelatihan ini adalah salah satu kegiatan yang amat penting bagi para guru untuk secara ilmiah dapat mengkaji masalah, menemukan strategi yang tepat, dan melaksanakan starategi tersebut secara sistematis.

\section{Metode Pelaksanaan}

Metode pelaksanaan dalam kegiatan ini adalah berupa pelatihan penyusunan proposal penelitian tindakan kelas dengan tahapan sebagai berikut; 1) Tim dosen yang merupakan narasumber memaparkan materi tentang konsep atau teori PTK dan mendeskripsikan sistematika penulisan proposal PTK secara ilmiah, 2) peserta pelatihan dalam hal ini para guru sekolah dasar di gugus 3 kecamatan Ende diminta untuk mengidentifikasi berbagai persoalan yang ditemukan atau yang dihadapi dalam pembelajaran di kelas, yang kemudian didiskusikan secara bersama-sama dengan tim dosen, 3) para guru kemudian dibentuk dalam kelompok sesuai dengan masalah yang mereka temukan yang disesuaikan dengan mata pelajaran di sekolah, kemudian mulai menyusun draft proposal PTK mulai dari deskripsi latar belakang masalah sampai pada desain prosedur pelaksanaan PTK serta referensi-referensi yang digunakan sebagai sumber ilmiah dalam melaksanakan penelitian, 4) setelah menyusun draft proposal PTK setiap kelompok diminta satu orang guru untuk persentasi mewakili kelompoknya masing-masing, kemudian draft proposal tersebut dibahas secara bersamasama.

\section{Hasil dan Pembahasan}

Pelatihan PTK diawali dengan pemaparan materi oleh pemateri tentang konsep PTK dalam mengatasi masalah dan meningkatkan kualitas pembelajaran sesuai dengan mata pelajaran yang ada dalam kurikulum SD secara umum. Pada tahap ini tim menjelaskan secara sistematis tentang konsep dan sistematika proposal PTK. Penjelasan secara sistematis tentang konsep PTK tentu membantu para guru untuk memahami PTK secara lebih dalam.

Penelitian Tindakan Kelas meliputi tiga kata, yaitu: penelitian, tindakan dan kelas. Pertama, penelitian adalah kegiatan mencermati suatu objek, menggunakan aturan metodologi tertentu untuk memperoleh data atau informasi yang bermanfaat bagi peneliti atau orang-orang yang berkepentingan dalam rangka peningkatan kualitas di berbagai bidang. Kedua, tindakan merupakan suatu gerak kegiatan yang sengaja dilakukan dengan tujuan tertentu yang dalam pelaksanaannya berbentuk rangkaian periode atau siklus kegiatan. Ketiga, kelas adalah sekelompok peserta didik yang dalam waktu yang sama dan tempat yang sama menerima pelajaran yang sama dari seorang guru (Arikunto, 2008). Lebih lanjut Arikunto (2008) menjelaskan bahwa PTK adalah penelitian tindakan yang dilakukan di 
kelas dengan tujuan memperbaiki atau meningkatkan mutu praktik pembelajaran. Selain itu Wibawa (2004) menjelaskan bahwa penelitian tindakan kelas adalah suatu penelitian yang mengangkat masalah-masalah aktual yang dihadapi oleh guru dilapangan.

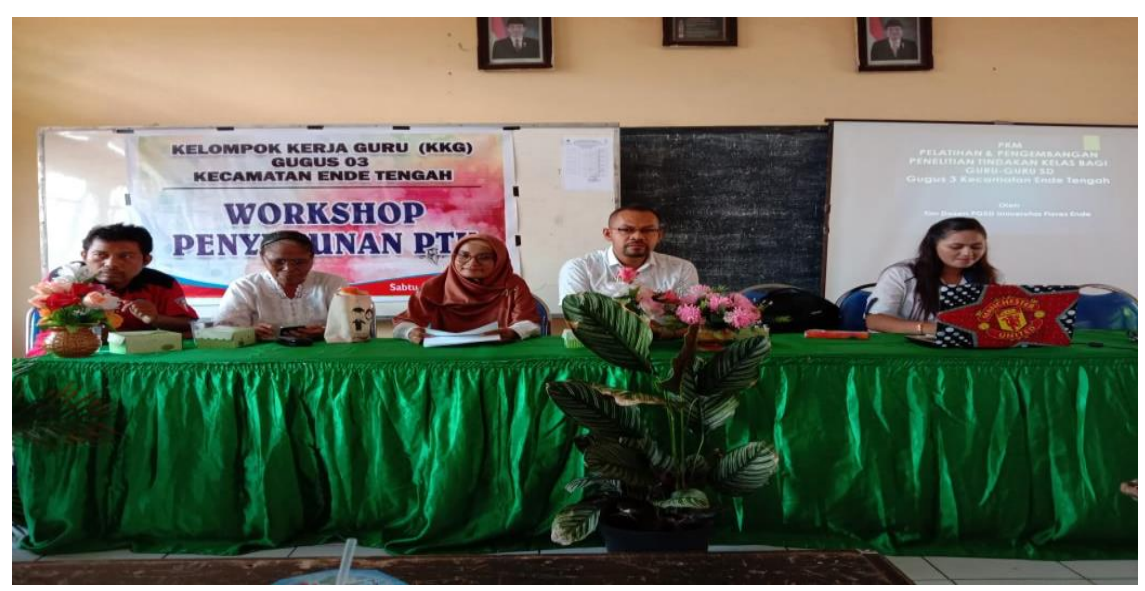

Gambar 1. Pemaparan Materi PTK oleh Tim

Setelah Tim memaparkan materi PTK setiap guru diberikan kesempatan untuk mengidentifikasi perbagai aspek pendidikan yang dapat di teliti dengan menggunakan metode PTK.

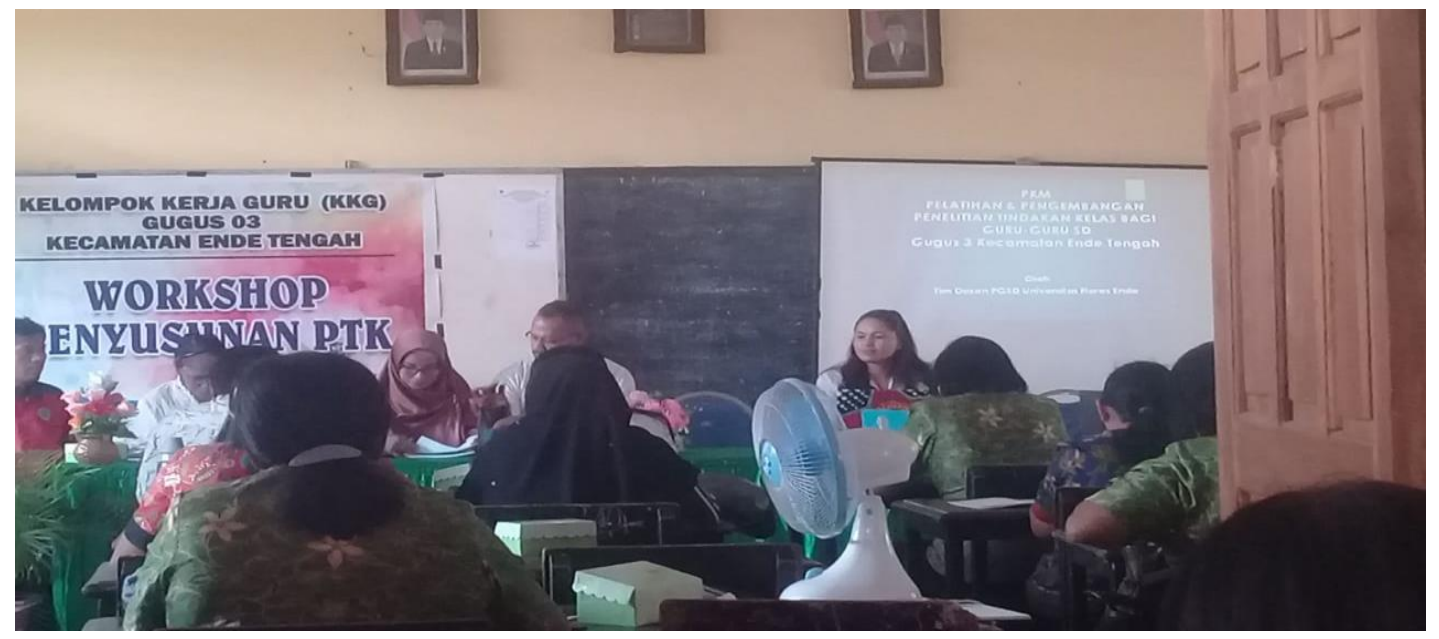

Gambar 2. Para guru sedang aktif mengkaji masalah pembelajaran di kelas.

Dalam tahap ini tim lebih mengarahkan para guru untuk secara detail mengungkapkan semua persoalan yang terjadi di dalam kelas yang menjadi penyebab tidak tercapainya kualitas pembelajaran yang baik, secara khusus pada proses pembelajaran itu sendiri. Tahap ini adalah tahap penting di mana para guru juga dirangsang untuk mampu secara jujur mengungkapkan kekurangan-kekurangan baik yang ada pada dirinya, siswa, sarana atau fasilitas belajar di sekolah dll.

Menurut Suhardjono (dalam Arikunto; 2008) masalah praktik pembelajaran di sekolah yang dapat dikaji adalah: 1). Siswa; misalkan: motivasi belajar, prestasi belajar, kesalahan pembelajaran siswa, dll; (2) guru; misalkan: metode mengajar, membimbing siswa, program pengajaran (materi pelajaran atau sistem evaluasi, misalnya kesesuaian materi pelajaran dengan kurikulum, sistem evaluasi berbasis kompetensi; (3) 
sarana dan prasarana belajar, misalkan: media pembelajaran, laboratorium; (4) hasil pembelajaran, misalkan; hubungan antara hasil pembelajaran dengan metode mengajar, sarana pembelajaran; (5) lingkungan, misalkan lingkungan sekolah, keluarga, masyarakat yang berkaitan dengan layanan pendidikan di sekolah, (6) pengelolaan sekolah atau kelas yang menunjang dalam pembelajaran misalkan teknik modifikasi perilaku kelompok, teknik memotivikasi kelompok, teknik pengembangan potensi sumber daya siswa.

Sesuai dengan tujuan kegiatan pelatihan PTK ini seperti yang telah diuraikan sebelumnya, maka para guru setelah memahami tentang PTK dan mengkaji berbagai persoalan yang terjadi di kelas, maka mereka perlu mendeskripsikan secara garis besar draft proposal penelitian PTK.

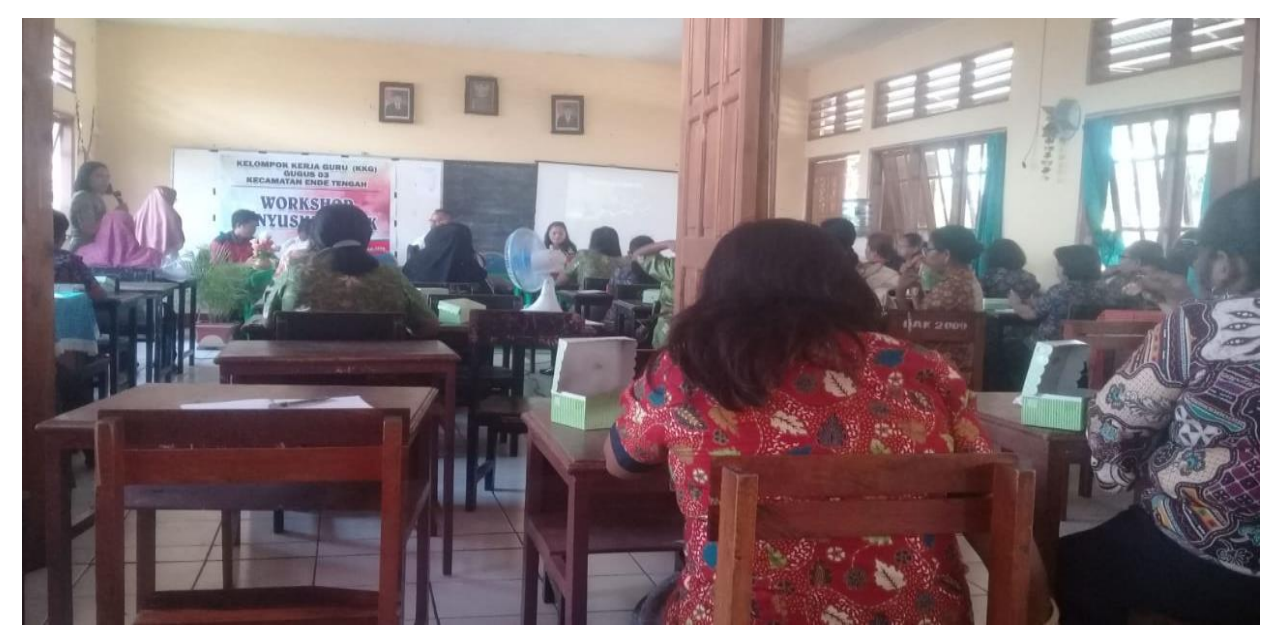

Gambar 3. Persentasi draft proposal oleh guru.

Pada tahap ini para guru masing-masing membuat draft proposal. Presentasi draft proposal bersifat representatif dan membuka ruang bagi guru yang bersedia saja untuk mempersentasikan rencana penelitiannya. Berdasarkan hasil pengamatan secara rata-rata para guru peserta pelatihan sudah kurang lebih mampu mendeskripsikan rencana penelitiannya dengan berpedoman pada prosedur penelitian yang secara umum bersumber dari Kemmis dan Mc Taggart. Untuk mempermudah tindakan dalam melaksanakan Penelitian Tindakan Kelas maka guru atau peneliti selalu merujuk pada prosedur penelitian yang secara garis besar akan dijelaskan berikut ini. Dasar rujukan prosedur penelitian ini diambil dari rincian prosedur penelitian yang dikembangkan oleh Kemmis dan Mc Taggart. Berikut bagan prosedur penelitian yang dapat dijadikan kompas dalam melaksanakan penelitian Tindakan kelas bagi para guru ataupun calon guru:

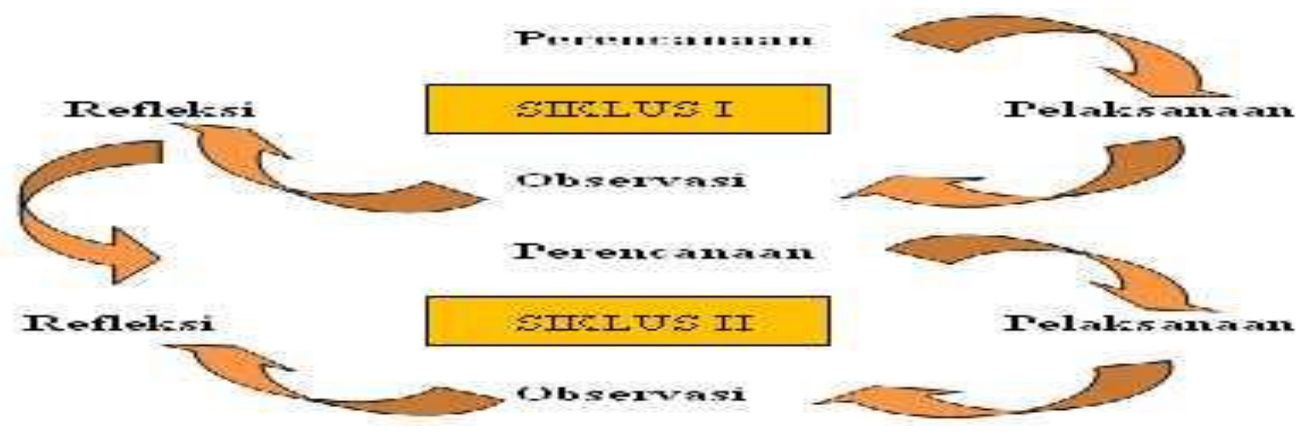


Gambar 4.Model Penelitian Tindakan Kelas Kemmis dan Taggart (dalam Ekawarna, 2013)

\section{Perencanaan Tindakan}

Yang dilaksanakan pada tahap ini adalah mengumpulkan informasi tentang situasi-situasi yang relevan dengan topik penelitian. Hasil pengumpulan informasi tersebut direfleksikan untuk menemukan sebuah fokus permasalahan yang pada saatnya menjadi dasar rujukan untuk menemukan pokok permasalahan. Bagi guru yang melakukan penelitian tentu dalam menemukan pokok masalah berdasarkan hasil evaluasi proses dan hasil pembelajaran yang telah guru tersebut laksanakan. Setelah menemukan pokok-pokok persoalan, maka peneliti baik guru maupun calon guru dapat mengkaji dan menentukan strategi pembelajaran yang tepat baik itu model, metode, maupun teknik yang dianggap tepat yang didukung dari berbagai literatur ilmiah berupa buku-buku maupun jurnal ilmiah. Hal ini dilakukan agar pokok persolan dapat teratasi dan tujuan pembelajaran diharapkan dapat tercapai. Pada tahap perencanaan peneliti menyiapkan RPP yang sudah dilengkapi dengan strastegi pembelajaran yang telah dipilih dan intrumen lainnya yang mendukung kegiatan penelitian, seperti LKS, Lembar Observasi, Format Evaluasi, Soal-soal Evaluasi dll.

\section{Tahap Pelaksanaan Tindakan}

Pelaksanaan tindakan sesungguhnya berkaitan dengan apa yang dilakukan peneliti dalam kerangka upaya perbaikan, peningkatan ataupun perubahan yang dilaksanakan berpedoman pada rencana tindakan yang telah dirancang. Pelaksanaan tindakan ini, merujuk pada pertimbangan teoritik dan empirik agar hasil yang diperoleh dapat diwujudkan.

\section{Tahap Observasi}

Pada tahap ini peneliti mengamati secara fokus proses pelaksanaan tindakan baik itu pada aktivitas siswa maupun guru. Tahap ini juga secara lengkap proses dan hasil pembelajaran diamati, agar memperoleh informasi yang valid.

Refleksi

Kegiatan refleksi sesungguhnya merupakan kegiatan analisis, sintetis dan interpretasi terhadap semua informasi yang diperoleh saat pelaksanaan tindakan melalui hasil observasi. Dalam kegiatan ini, peneliti mengkaji, melihat, dan mempertimbangkan hasil- hasil atau dampak dari masing-masing tindakan berkenaan dengan penerapan dari Strategi pembelajaran yang dipakai baik itu berupa model, metode, maupun teknik pembelajaran.

\section{Simpulan dan Tindak Lanjut}

Berdasarkan hasil dan pembahasan dapat disimpulkan bahwa kegiatan pelatihan penyusunan proposal bagi para guru SD di gugus 3 kecamatan Ende berdampak positif terhadap profesionalitas guru yaitu; guru dapat memahami secara baik tentang konsep atau teori PTK, dapat secara fokus menentukan masalah penelitian, dapat menentukan tindakan yang diasumsikan merupakan tindakan yang tepat berdasarkan kajian literatur ilmiah, serta dapat menyusun draft proposal PTK. Dengan demikian sebagai bentuk tindak lanjut dari kegiatan ini adalah draft proposal yang telah buat 
oleh para guru akan disempurnakan, yang kemudian akan implementasikan dalam bentuk penelitian.

\section{Daftar Pustaka}

Arikunto, S. 2008. Prosedur Penelitian Suatu Pendekatan Praktek. Jakarta : Rineka Cipta.

Arikunto, S. 2010. Penelitian Tindakan Kelas. Jakarta: Bumi Aksara

Arifin, Z. 2010. Penelitian Pendidikan Metode dan Paradigma Baru. Bandung: Remaja Rosdakarya

Ekawarna. E. 2013. Penelitian Tindakan Kelas. Jakarta: Gaung Persada

Taniredja, T. 2012. Penelitian Tindakan Kelas Untuk Pengembangan Profesi Guru. Bandung: Alfabeta

Trianto, T. 2010. Mendesain Model Pembelajaran Inovatif Progresif. Jakarta: Kencana

Wibawa. W. 2004. Penelitian Tindakan Kelas (PTK). Bandung: PT Alfabeta 